\title{
Nutrient and microbial dynamics in eutrophying shrimp ponds affected or unaffected by vibriosis
}

\author{
Hugues Lemonnier ${ }^{\mathrm{a}, ~}{ }^{*}$, Claude Courties ${ }^{\mathrm{b}, \mathrm{c}}$, Chantal Mugnier ${ }^{\mathrm{a}}$, Jean-Pascal Torréton ${ }^{\mathrm{d}, 1}$ and Alain \\ Herbland $^{\mathrm{a}}$
}

\footnotetext{
a IFREMER, LEAD, BP 2059, 98846 Nouméa cedex, New Caledonia

b UPMC Univ. Paris 06, FRE 3247, MBCE, Observatoire Océanologique, F-66651, Banyuls/mer, France

${ }^{c}$ CNRS, FRE 3247, MBCE, Observatoire Océanologique, F-66651, Banyuls/mer, France

d IRD UR103-ECOLAG/UMR 5119, Université Montpellier II, CC 093, 34095 Montpellier Cedex 05, France

${ }^{1}$ Present address: IRD, Van Phuc Diplomatic Compound Appt. 202, Bldg. 2G. 298, Kim Ma. Ba Dinh, Hanoi, Vietnam.
}

*: Corresponding author : H. Lemonnier, Tel.: +687 3548 87; fax: +687 3511 77, email address : Hugues.Lemonnier@ifremer.fr

\begin{abstract}
:
A field survey was conducted on two intensive shrimp farms using similar technical practices: one (DF) historically affected by a vibriosis, the other $(\mathrm{HC})$ in which the pathogen has been observed although no mortality event has occurred. Because historical data suggest that eutrophication process may directly or indirectly play a role in the disease outbreak, we focussed our research on its dynamics. A higher variability of the phytoplanktonic compartment linked to an imbalance in the molar N:P ratio was observed in farm DF compared to farm HC, implying a modification on the linkage between the bacteria and phytoplankton compartments at DF. The beginning of the mortality outbreak at DF followed a shift from pico- to nanophytoplankton. The organic matter mineralization process at the water-sediment interface may explain the disturbance observed in the water column during eutrophication. The consequences of this disturbance on shrimps' health status and pathogen ecology are discussed.
\end{abstract}

Keywords: Aquaculture; Shrimp; Eutrophication; Ecosystem shift; Phytoplankton; Vibriosis 


\section{Introduction}

Disease in marine aquaculture is described as the end result of complex interactions between the host, its environment, and the pathogen itself. This is illustrated by Snieszko's (1974) famous diagram of three intersecting circles. In this "epidemiological triad", the host status may vary (species, strain, age, life stage, nutritional status, etc.); the pathogen may vary in virulence, concentration, ability to circumvent the host's defences, etc.; and the environment may vary from the ideal to one that more favours the development of the disease. The factors of pathogen(s), host(s) or agent(s), and environment must all be considered by diagnosticians in determining the cause of a disease (Lightner and Redman, 1998).

In New Caledonia, the disease known as Summer Syndrome is responsible for seasonal mortalities affecting Litopenaeus stylirostris shrimp reared in earthen ponds. It was first identified in December 1997 in an intensive farm (called diseased farm, DF) and has been enzootic ever since, subsequently affecting a second (2003) and third farm (2005), both close to DF. Regarding the pathogen, experimental pathology and molecular epidemiology studies have demonstrated that this disease is caused by a single emerging cluster of a highly virulent strain of Vibrio nigripulchritudo (Goarant et al., 2006a; 2006b, Reynaud et al., 2008). However, as observed for many pathogenic Vibrio, the presence of this strain in the ecosystem does not necessarily lead to disease (Goarant et al., 2007). Regarding the host, historical analysis of DF grow-out data shows that the first dead shrimps appear after $58 \pm 8$ days of rearing for an average shrimp weight of about $5 \mathrm{~g}$, and disappear after about 120 days (Lemonnier et al., 2006). During an aquaculture production cycle, feed supply in shrimp pond increases proportionally to the stocking biomass and induces an increasing eutrophication level in the pond ecosystem. Mortality outbreaks occurred during particular phases of the eutrophication process (Lemonnier et al., 2006). We hypothesise that this process could play a 
role by directly or indirectly inducing stress for shrimp and/or increasing the growth and/or virulence factors of $V$. nigripulchritudo.

In order to describe the eutrophication process and events related to shrimp mortality, a high frequency field survey was conducted in two ponds located in two grow-out intensive farms, one a farm historically affected by the disease (DF), the other a "control" farm (HC) where the pathogen had been observed without mortality. In eutrophying ponds, the analysis of this process implies to study the role of bacteria and phytoplankton (Burford et al., 2003a). Stability in the stocking biomass and metabolic activity of phytoplankton communities is critical to maintain a suitable environment for cultured animals. Heterotrophic bacteria are an important component of the food web structure and biogeochemical cycles. Aerobic and anaerobic microbial processes can affect the community respiration, $\mathrm{pH}$ levels and ammonia concentrations. Furthermore, heterotrophic bacterial activity mediates the recycling of nutrients such as nitrogen and phosphorus which can subsequently stimulate primary production. The study was designed to follow by means of flow cytometry the dynamics of phytoplankton and bacterioplankton communities in the two ponds concomitantly to a classical environment monitoring (oxygen, nutrients, chlorophyll $a$ ). Bacterial production was also used as an index of available organic matter for bacteria to characterize the trophic status of the ponds (Ducklow and Carlson, 1992). Several indicators proposed by Hussenot and Martin (1995) and Avnimelech et al. (2001) were also followed to assess the eutrophic state of sediment in field conditions. This research had three objectives: (i) to describe the eutrophication dynamics in a healthy intensive pond, (ii) to compare the environmental conditions between the "healthy" and the "disease" ponds, and (iii) to discuss briefly the consequences on the ecophysiology of reared shrimp and the pathogen ecology.

\section{Materials and methods}




\subsection{Field survey}

During the 2002-2003 austral summer, a field survey was conducted on two farms, the first considered as a "control" farm (HC), the second affected by the disease since 1997 (DF). The two farms surveyed are close to each other (about $15 \mathrm{~km}$ ). They have similar pond sizes between 3 and 4.5 ha, and similar intensive culture practices, for a total surface of 29 ha (HC) and 34 ha (DF), respectively. The ponds were dried out 5 months before filling and were stocked at day $0(\mathrm{~d} 0)$ with $L$. stylirostris post-larvae, originating from the same hatchery batch. Initial stocking density was 35 shrimps $\mathrm{m}^{-2}$ at $\mathrm{HC}$ and 28 shrimps $\mathrm{m}^{-2}$ at DF. For both farms, shrimps were fed daily with the same local commercial feed (including 35-40\% protein). The ponds were managed by the two farmers according to their usual techniques without advice from the scientific team. At the outset, urea was added to the ponds to fertilize the water column. At $\mathrm{HC}, 6.7 \mathrm{~g} \mathrm{~m}^{-2}$ were added to the pond over a 15-day period. This was stopped 1 day before stocking with post-larvae. At DF, $7.0 \mathrm{~g} \mathrm{~m}^{-2}$ were used over a 40-day period, starting 10 days before stocking with post-larvae. Daily water exchange in the ponds was implemented, ranging from $5 \%$ to $40 \%$ of the total pond volume depending on the shrimp biomass. Mechanical aeration was regularly used in both ponds in relation to the shrimp biomass in the ponds. On each farm, daily pond mortalities were evaluated by counting dead and moribund shrimps at the pond edges.

\subsection{Field sampling}

Water column

Weekly water samplings were carried out in the morning (06:00) and the afternoon (16:00) from the beginning of the rearing until the 32nd rearing day (d32) in both farms and, subsequently, every other day alternately on one farm and the other. Sampling was conducted for each pond in three stations, located variously in the middle of the pond, near the discharge 
gate and opposite the discharge gate, and at two depths. Spatial analysis of a number of parameters (temperature, salinity, turbidity, dissolved oxygen, $\mathrm{pH}$, total ammonia nitrogen, nitrite, mineral matter, total suspended matter and chlorophyll a) was carried out at six stations, including the three stations described above, once a week during the survey. These specific results are not presented. Sub-surface (15 cm deep) samples were collected using a 21 polyethylene bottle. Bottom sub-samples $(5 \mathrm{~cm}$ above sediment) were carefully pumped into a bottle through silicone tubing, avoiding disturbance of the sediment. In sum, no significant spatial variability in the water column was observed except for mineral matter concentrations, suggesting that water column was well mixed and that a single sampling at two depths was representative of the whole pond (Lemonnier, 2007). Dissolved oxygen (DO) and pH were recorded in situ at each station (bottom and surface) with portable oxygen and $\mathrm{pH}$ meters (WTW oxi $315 \mathrm{i}$ and WTW pH 340i). Temperature was automatically and continuously measured using an Optic StowAway Temp Logger (Aquatic Eco-systems, USA). Located near the ponds' discharge gate, this operated at two depths $(15 \mathrm{~cm}$ below the surface and $5 \mathrm{~cm}$ above the bottom) with a 15-min step.

\section{Sediment}

Sediment samplings were carried out in six stations per pond. Samples were taken at the end of the pond dry-out, just before filling it, and weekly during grow-out. The first $\mathrm{cm}$ layer of soil was sampled using a $40 \mathrm{~cm}$ long PVC tube of $10 \mathrm{~cm}$ diameter by scuba diver to minimize sediment disturbance. $\mathrm{pH}$ and redox potential (Eh) were assessed at each station according to the method described by Hussenot and Martin (1995). Eh was measured with a combined platinum electrode (PT5700A, Schott Instruments, Mainz, Germany). pH was measured directly in the wet sediment. 


\subsection{Laboratory analysis}

\subsubsection{Water column}

The following parameters were analysed on samples (surface and bottom) collected near the discharge gates only: soluble reactive phosphorus, nitrate and nitrite, dissolved organic carbon, dissolved organic nitrogen, particulate organic carbon, particulate nitrogen, bacterial abundance and production.

Physico-chemical parameters

In the field laboratory, salinities were measured using a refractometer. Waters samples (250 $\mathrm{ml}$ ) were immediately filtered through a GF/C Whatman filter to analyse total suspended solid (TSS). Mineral matter (MM) and particulate organic matter (POM) were evaluated by loss on ignition at $450{ }^{\circ} \mathrm{C}$ during $4 \mathrm{~h}$.

\section{Nutrients}

Waters samples $(500 \mathrm{ml})$ were immediately filtered through a GF/F Whatman filter. Colorimetric analyses for total ammonia nitrogen (TAN) and dissolved inorganic phosphorus (DIP) were carried out on fresh samples using a Spectronic Genesis 5 spectrophotometer (Thermo Electron Corporation) equipped with a $10 \mathrm{~cm}$ cell. TAN was measured using methods described by Koroleff (1976) and DIP according to the molybdenum blue reaction described by Murphy and Riley (1962). Nitrate and nitrite $\left(\mathrm{N}_{\mathrm{ox}}\right)$ were determined on thawed samples using standard colorimetric techniques on a Bran + Luebbe autoanalyser III system according to Raimbault et al. (1990). $\mathrm{N}_{\mathrm{ox}}$ and TAN concentrations were added to calculate dissolved inorganic nitrogen (DIN).

Dissolved organic matter 
Water samples $(100 \mathrm{ml})$ were immediately filtered through a muffled GF/F Whatman filter. Filtrates were collected in muffled tubes and stored frozen until analysis. Dissolved organic nitrogen (DON) was analysed following oxidation described by Raimbault et al. (1999). Preoxidation DIN concentrations were subtracted from the post-oxidation total dissolved nitrogen (TDN) to derive the DON concentrations. DOC concentrations were measured by high temperature catalytic oxidation on a Shimadzu TOC-V Total organic carbon analyzer.

Particulate organic matter

Total particulate nitrogen $(\mathrm{PN})$ and carbon $(\mathrm{POC})$ concentrations were determined by filtering (25-50 ml) onto a combusted Whatman GF/F filter on a Carlo-Erba Nitrogen-Carbon Analyzer (Hedges and Stern, 1984). Decarbonatation with $\mathrm{H}_{2} \mathrm{SO}_{4}$ were performed before analysis. Acetanilide was used as standard.

\section{Chlorophyll $a$}

Water samples from 25 to $50 \mathrm{ml}$ were filtered through Whatman GF/F filters and analysed by the classical fluorometric method before and after acidification (Holm-Hansen et al., 1965). The fluorimeter (Turner TD700) was calibrated using pure Chl $a$ (Sigma). The size fractioned chlorophyll $a(\mathrm{Chl} a)$ concentrations were also determined on sub-samples, using $2 \mu \mathrm{m}$ Nuclepore membranes and $20 \mu \mathrm{m}$ nylon sieves by means of the same fluorometric method.

Flow cytometry measurements (FCM)

Sub-samples of $2.0 \mathrm{ml}$ were preserved with $1 \%$ glutaraldehyde (final concentration) and stored in liquid nitrogen pending flow cytometric analysis applied to phytoplankton and bacteria populations (Vaulot et al., 1989). Samples were quickly thawed at room temperature and then analysed using a FACSCan flow cytometer (BD-Biosciences, San Jose, CA) 
equipped with an air-cooled argon laser $(488 \mathrm{~nm}, 15 \mathrm{~mW})$. Fluorescent $1.002 \mu \mathrm{m}$ beads (Polysciences Inc., Europe) used as an internal standard were systematically added to each analysed sample in order to normalize cell properties and to compare cell populations. Accurately analysed volumes and subsequent estimations of cell concentrations were calculated by measuring the remaining volume and subtracting it from the initial sub-sample volume $(1 \mathrm{ml})$.

- FCM phytoplankton abundance

Phytoplanktonic cells were discriminated and enumerated according to their right-angle light scattering properties (SSC, roughly related to cell size) and orange (560-620 nm) and red (>670 nm) fluorescence due to phycoerythrin and chlorophyll pigments, respectively.

- FCM bacterial abundance

After thawing samples for bacterial counts, $1 \mathrm{ml}$ sub-samples were incubated with SYBRGreen I nucleic acid stain (Molecular Probes) according to Marie et al. (1997) for 15 min at room temperature in the dark. Total bacterial cells were enumerated (TBA) and two clusters of bacteria - high nucleic acid content (HNA bacteria) and low nucleic acid content (LNA bacteria) - were differentiated according their variations of light scatter properties (relative cell size) and green fluorescence related to nucleic acid content (Lebaron et al., 2001).

\section{Bacterial production measurements}

Bacterial production (BP) was determined from $\left[{ }^{3} \mathrm{H}-m e t h y l\right]$ thymidine incorporation rates using the microcentrifuge method (Smith and Azam 1992). Triplicate $1.0 \mathrm{ml}$ water samples were incubated in the dark at in situ temperature for 30 min with $\left[{ }^{3} \mathrm{H}\right]$-thymidine (final concentration $15 \mathrm{nM}, 1.8 \mathrm{TBq}^{\mathrm{mmol}}{ }^{-1}$, Amersham). One control killed with $150 \mu \mathrm{l}$ of $50 \%$ 
Trichloroacetic acid (TCA) was run corresponding to every live incubation. Except in the control, the activity was stopped by $150 \mu 1$ of $50 \%$ TCA. After allowing precipitation for 15 min at $2{ }^{\circ} \mathrm{C}$, labelled material was collected following centrifugation $(10 \mathrm{~min}$ at $13,000 \mathrm{~g})$. The pellet was rinsed three times with $1 \mathrm{ml}$ of ice-cold 5\% TCA and samples were stored at -20 ${ }^{\circ} \mathrm{C}$ until radioactivity determination. Scintillation counting was effected using a TriCarb 1600 TR after addition of $1 \mathrm{ml}$ of Ultima Gold MV and taking quenching correction into account. The coefficient of variation for triplicate determinations was $8 \%$ on average. The biomass production rates were computed using the average empirically determined conversion factor of $2.91 \times 10^{18}$ cells mol $^{-1}$ of thymidine (Briand et al., 2004). The bacterial carbon production was calculated with a carbon per cell conversion factor of $30.2 \mathrm{fgC} \mathrm{cell}^{-1}$ (Fukuda et al., 1998).

\subsubsection{Sediment}

Particle size was determined by wet sieving $(2000-50 \mu \mathrm{m})$ and pipetting $(<50 \mu \mathrm{m})$ following treatment with $35 \% \mathrm{H}_{2} \mathrm{O}_{2}$ and dispersion through overnight shaking with Na-resin (Bartoli et al., 1991). Soil texture was identified with soil triangle (Boyd, 1995) but only at the end of the pond dry-out, before filling the pond. During the survey, samples were homogenized. Subsamples $(100 \mathrm{~g})$ were centrifuged at $2000 \mathrm{~g}$ for $20 \mathrm{~min}$ and pore water collected. TAN concentrations in pore water were measured by the Koroleff method (1976) adapted to seawater and DIP, according to the molybdenum blue reaction described by Murphy and Riley (1962). Concentrations of organic matter (LOI) were determined in another sub-sample by ignition of the dry sediment at $350{ }^{\circ} \mathrm{C}$ for $8 \mathrm{~h}$ (Quieroz and Boyd, 1998). The Kjeldhal method was used to determine TN (Nelson and Sommers, 1982). Total organic carbon (TOC) was measured by the Walkley-Black potassium dichromate-sulfuric acid oxidation method 
with external heating (Boyd, 1995). Total phosphorus (TP) was determined after a digestion by $\mathrm{NaOH} / \mathrm{H}_{2} \mathrm{SO}_{4}$ using a Technicon Autoanalyser (Treguer and Le Corre, 1975).

\subsection{Data and statistical analysis}

Spearman rank correlation coefficients were used in order to characterize the relation between parameters and time. The correlations between parameters were examined using Pearson's correlation matrix. Comparison of data from the two ponds were assessed using ANCOVA with pond as factor and feed as cofactor. Data were normalized using $\log (x+1)$ transformation before parametric analysis.

\section{Results}

\subsection{Shrimp mortality}

No mortalities linked to Summer Syndrome were recorded in HC pond and the final survival of shrimp was estimated by the farmer to be $62 \%$. In DF pond, the first mortalities were observed around d50 (Fig. 1a), when the mean weight of shrimp was $5.9 \pm 0.1 \mathrm{~g}$. Two main mortality periods were observed: the first between $\mathrm{d} 54$ and d64, the second characterized by a peak at d77. Final shrimp survival estimated by the farmer was $27 \%$.

\subsection{Nitrogen and phosphorus inputs in ponds}

Nitrogen and phosphorus inputs by feeding and pond fertilization showed a similar increasing trend in both ponds over the course of the survey (Fig. 1b). However, after d65, the contribution of $\mathrm{N}$ and $\mathrm{P}$ by feeding was reduced in $\mathrm{DF}$ compared to $\mathrm{HC}$ because of the decreased shrimp biomass due to a mortality outbreak.

\subsection{Water column}


Daily mean water temperature was $28.9 \pm 0.9^{\circ} \mathrm{C}$, showing no statistical difference between ponds (range $21.8-32.7^{\circ} \mathrm{C}$, Fig. 1a). Oxygen concentration at $6 \mathrm{~h} 00$ am showed a significant decreasing trend with time in both ponds (Fig. 2a, Table 1). Concentrations were significantly lower at $\mathrm{DF}$ than at $\mathrm{HC}$ after $\mathrm{d} 40(\mathrm{p}<0.05)$. Net oxygen budget increased significantly during the survey for both ponds (Fig. 2b, Table 1). However, DF showed higher day-to-day temporal variations of net oxygen budget than HC. A significant decreasing trend of morning $\mathrm{pH}$ was observed during the survey (Table1). Mean morning values ranged between 7.8 and 8.7. Salinity varied between 37 and 41 (95\% of the measurements). Mean value was around 2 higher at DF than at $\mathrm{HC}$ during the 40 first days of rearing, and similar thereafter.

TAN represented $83 \%$ of DIN into each pond. Three TAN concentration peaks were observed at $\mathrm{DF}$, respectively, at $\mathrm{d} 36, \mathrm{~d} 50$ and $\mathrm{d} 64$. No similar TAN variations were found in $\mathrm{HC}$ (Fig. 3a). The average nitrite-nitrate concentration was similar in both ponds. This remained weak and ranged between 0.05 and $0.15 \mu \mathrm{mol} \mathrm{l}^{-1}$. For both ponds, phosphates ranged between 0 and $0.1 \mu \mathrm{mol} 1^{-1}$. Three DIN/DIP ratio peaks, related to the increase of TAN concentrations, were observed in DF, whereas only a small peak occurred at HC (Fig. 3b). Mean DIN/DIP ratios were $31 \pm 26$ (range 4-117) in the HC pond and $45 \pm 52$ (range 1-195) at DF.

Overall trends of DON concentrations were similar in both ponds. However, averages were significantly higher $(\mathrm{p}<0.01)$ at $\mathrm{DF}\left(33.6 \mu \mathrm{mol}^{-1}\right)$ than at $\mathrm{HC}\left(22.6 \mu \mathrm{mol} 1^{-1}\right)$. Except at d0, DOC showed similar trends in both ponds with values ranging between 220 and $920 \mu \mathrm{mol} \mathrm{l^{-1 }}$.

The trend of Chl $a$ distribution was nearly exponential in both ponds (fig. 4a), with a higher variability at DF than HC. Three main peaks were observed at DF at d44, d56 and d80, while only two main peaks were measured at HC on d60 and d80 (Fig. 4a). During the first 40 days, 
picophytoplankton dominated the autotrophic compartment. Chl $a$ fraction $<2 \mu \mathrm{m}$ reached up to $80 \%$ of the total $\mathrm{Chl} a$ biomass (Fig. $4 \mathrm{~b}$ ). Nanophytoplankton cells dominated the second part of the rearing (Fig. 4c). The shift from pico- to nanophytoplankton was observed in relation to the beginning of the mortality outbreak. The nanophytoplankton were more unstable in the DF pond than in the HC pond. In both ponds, correlations between Chl $a$ and POC on the one hand ( $\mathrm{r}>0.89)$, and between $\mathrm{Chl} a$ and PON on the other ( $\mathrm{r}>0.87)$, were highly significant (Table 2). The temporal trends of particulate organic matter (POC, PON, POM) mirrored those of Chl $a$ (Table 2). DIN and DIP in DF were, respectively, negatively (r $=-0.42)$ and positively $(r=0.40)$ correlated to phytoplankton biomass (Table 2$)$.

Heterotrophic bacteria had very high abundances $\left(>10^{7} \mathrm{ml}^{-1}\right)$ and their distributions showed strong temporal variations (Fig. 5a). In both ponds, correlations between TBA and HNA abundance were highly significant (Table 2). The \% HNA bacteria fraction was highly variable and ranged from $34 \%$ to $67 \%$ (Fig. 5b). Bacterial production (BP) was stable in both ponds until d30 (around $18 \mu \mathrm{g} \mathrm{C} \mathrm{L}^{-1} \mathrm{~h}^{-1}$ ). It then increased progressively, reaching $130 \mu \mathrm{g} \mathrm{C} \mathrm{^{- }}$ ${ }^{1} \mathrm{~h}^{-1}$ (Fig. 5c). Correlations of BP vs. Chl $a$ and BP vs. distributed food for shrimp were significant for both ponds $(\mathrm{p}<0.01)$ (Table 2). However, the correlation coefficient between $\mathrm{BP}$ and Chl $a$ was higher at $\mathrm{HC}$ than at DF. Other relationships between BP and different environmental parameters were found in HC, such as: HNA abundance, temperature, DOC and POC (Table 2).

\subsection{Sediment}

Before the ponds were filled, there was no significant difference $(p>0.05)$ whatever the parameter studied (clay and silt content, $\mathrm{pH}, \mathrm{TN}, \mathrm{TOC}, \mathrm{TP}$ ) except for the fine sand content, which was higher in $\mathrm{HC}$ (22\% of total content) than in DF $(9 \%)$. Mean $\mathrm{pH}$ was close to 
neutrality. Values ranged between 6.1 and 8.1, depending of the sampling station and pond. TN, TOC and TP concentrations ranged between 0.7 and $1.8 \mathrm{mg} \mathrm{g}^{-1}, 10$ and $19 \mathrm{mg} \mathrm{g}^{-1}$ and 0.78 and $1.55 \mathrm{mg} \mathrm{g}^{-1}$, respectively.

Redox potential and $\mathrm{pH}$ decreased significantly during shrimp grow out at HC (Table 3, Fig. 6a and b). Mean $\mathrm{pH}$ and potential redox were higher in $\mathrm{HC}$ than in DF. Sixty eight percent of $\mathrm{pH}$ values were lower than 6.6 in DF compared to $15 \%$ in HC. During the survey, TAN concentrations ranged from 0.03 to $7.7 \mathrm{mg} \mathrm{l}^{-1}$ in $\mathrm{HC}$ and from 0.01 to $16.5 \mathrm{mg}^{-1}$ in DF. A significant increase of TAN concentrations during the survey was observed in DF $(p<0.01)$ but not in HC (Table 3). After d50, the average TAN concentrations were generally higher in DF than in $\mathrm{HC}$ (Fig. 6c). A significant increase of LOI, TOC and TN in both ponds was observed during the rearing (Table 3, Fig. 6d). The correlations between LOI, TOC and TN were highly significant (Table 4). The increase of organic matter in sediment was associated with a decrease of the $\mathrm{C} / \mathrm{N}$ ratio between the beginning of the rearing until around $\mathrm{d} 50$ (Fig. 6e, Table 3). Around d50, mean values of the $\mathrm{C} / \mathrm{N}$ ratio were $7.3 \mathrm{in} \mathrm{HC}$ and 8.1 in the $\mathrm{DF}$ pond. Mean TP concentrations were higher in $\mathrm{HC}$ than in DF throughout the rearing (Fig. 6f).

\section{Discussion}

\subsection{Eutrophication dynamics in the control pond (HC)}

Eutrophication of this intensive pond ecosystem has traditionally been related to an increase of phytoplankton biomass, a decrease of DO concentration in the morning and an increase of net oxygen budget (Martin et al., 1998). The observed nutrient concentrations cannot explain the increase of phytoplankton in terms of the number of cells and biomass during the second part of the survey. However, low ambient concentrations of nutrients do not necessarily mean 
that the phytoplankton growth rate was limited, since mineralization of organic matter in pond sediment can be a considerable nutrient source for phytoplankton growth (Burford and Longmore, 2001). Nutrient produced by organic matter degradation is rapidly assimilated by plankton, implying low concentration in the water column (Burford et al., 2003b). TAN was typically the dominant form of inorganic nitrogen found in shrimp ponds. The N:P ratio was found to be highly unbalanced compared to the values quoted in the literature, which range from 5.5 to 67 in intensive systems (Alonso-Rodríguez and Páez-Osuna, 2003). Sixty-three percent of N:P ratio values were higher than the Redfield molar ratio of 16:1, usually taken as optimal for balanced growth. This result suggests that phosphate is more limiting than nitrogen, especially after d50. However, the use of this ratio to characterize the limiting factor of primary production is controversial because it is not based on readily available nutrient pools for cell growth, and there is evidence that in many eutrophic systems phytoplankton is not limited by nutrient (Sommaruga and Robarts, 1997). However, it has been shown that limitation of phytoplankton by $\mathrm{N}$ is possible when $\mathrm{P}$ loads are excessive (Frederick et al., 1993). The $\mathrm{N}: \mathrm{P}$ molar ratio of feed was 10.4 , indicating that $\mathrm{N}$ input by feed was excessive comparatively to $\mathrm{P}$ input and this imbalance increased with grow-out time, supporting the hypothesis that $\mathrm{P}$ became the limiting factor in pond. The eutrophication process was also associated with an increase of phytoplankton size. If picophytoplankton represented the major contribution to the phytoplanktonic compartment (in terms of cell number and biomass) at the beginning of the rearing (day 0 to day 40 ), this contribution clearly decreased toward day 50 . Fernández et al. (2003) reported that multiplication of larger cells is faster than that of smaller cells when they are not limited by nutrient diffusion. The trophic status of the water is also reported by Ducklow and Carlson (1992) as one of the most important affecting the bacterial compartment. The overall flux of bacterial production is taken as an index of organic matter available for bacteria, thus characterizing the richness of the environment. BP showed large 
temporal variation, and two periods could be distinguished in relation to eutrophication of the pond ecosystem. The first, from d0 to d40, showed values around $15 \mu \mathrm{g} \mathrm{Cl}^{-1} \mathrm{~h}^{-1}$, which were higher than values recorded in polluted tropical waters (Andrade et al., 2003) or in the lagoon of New Caledonia (Torréton et al., 2007). During the second period, from d40 to d80, the values were considerably higher and reached $120 \mu \mathrm{g} \mathrm{C}^{-1} \mathrm{~h}^{-1}$, much higher than those reported for a hypertrophic ecosystem (Sommaruga and Robarts, 1997). The relationship between the $\log$ of TBA and the $\log$ of thymidine incorporation indicate that TBA and BP were weakly coupled $(r=0.45)$. Nevertheless, the distribution of thymidine incorporation rate per cell (specific activity) increased linearly with time, suggesting an increase in the metabolic activity of cells related to the trophic status of the pond (results not presented). It was shown that HNA bacteria were the dominant bacterial fraction during the second part of the rearing, probably constituting the main active cells responsible for most of the total bacterial production in high-nutrient marine environments (Gasol et al., 1999). The HNA \% ranged from $34 \%$ to $67 \%$ and increased with DOC concentrations in the water column $(r=0.57, p<$ 0.01). Nevertheless, bacterial production measured is weakly correlated with HNA cell counts $(r=0.49)$, suggesting that the activity could be variable among HNA cells depending on the trophic status of the ecosystems, as shown by Lebaron et al. (2001). A part of BP could also be related to the LNA bacteria. This was indeed shown by Andrade et al. (2003) and Williams et al (2008) in a tropical or subtropical environment. The same is probably true in our study, where a significant, but low correlation was found between BP and LNA abundance ( $\mathrm{r}=$ $0.29)$.

Water temperature, ranging from 21.8 to 32.7 , played a major role in $\mathrm{BP}$, accounting for $59 \%$ of its variation. As found in some eutrophic ecosystems (Cole et al, 1988) and in the New Caledonia lagoon (Rochelle-Newall et al., 2008), BP was significantly correlated with Chl $a$ $(\mathrm{r}=0.61)$, suggesting that BP is partially supported by the organic carbon released by primary 
production. The significant linear regression between BP and feed could indicate that BP was also partially supported by organic carbon leached from feed. Regarding dissolved organic nitrogen, several authors have shown that a significant amount of dissolved nitrogen is leached from feed and faeces over the course of a few hours in shrimp ponds (Burford and Williams, 2001; Burford et al., 2002). A portion of these DON compounds (urea, dissolved primary amines) is rapidly utilized by the microbial community. Another portion (proteins or fragments of proteins, peptidoglycans remnants) is less effectively utilized and mostly accumulates in pond water (McCarthy et al., 1998). The measured DON concentrations were fairly constant and may be due to the dilution effect induced by the water exchange rates managed by farmers according to shrimp biomass (Lemonnier and Faninoz, 2006).

Most of the resultant uneaten feed, together with faeces production, senescent plankton and other detritus, inevitably settles on the pond bottom, inducing in the studied ponds a substantial increase in the organic matter content in sediment. The $\mathrm{C} / \mathrm{N}$ trend showed that the nitrogen content in the deposited organic matter was high (low $\mathrm{C}: \mathrm{N}$ ratio). Organic carbon was mainly consumed for respiration and released as $\mathrm{CO}_{2}$. When oxygen is depleted, other terminal electron acceptors can be used to mediate the decomposition of organic matter (Avnimelech and Ritvo, 2003). Redox potential, which is a method to evaluate the intensity of the pond anaerobic conditions, showed values ranging from $+87 \mathrm{mV}$ to $+302 \mathrm{mV}$ at the beginning of the rearing. These measurements suggest that several processes occurred within organic matter degradation, such as denitrification, fermentation, manganese and iron reduction (Avnimelech and Ritvo, 2003). After d30, redox measurements indicated that the sediment was close to suboxic conditions. $\mathrm{pH}$ changed with time, affected to a large extent by the accumulation of organic matter, which may increase the partial pressure of $\mathrm{CO}_{2}$ (Ponnamperuma et al., 1966). 


\subsection{Comparison of the eutrophication process between DF and $\mathrm{HC}$ ponds}

Regarding parameters sampled in the column water, both ponds presented relatively similar profiles (see trends of DO, $\mathrm{pH}$, salinity, Chl $a$, BP, BA, \% HNA, DOC). However, the DF pond was characterized by an accumulation of DON and a higher variability in the phytoplanktonic compartment in relation to weak correlation coefficients between the bacterial and phytoplanktonic compartments. Thus bacterial production variability was best related to $\mathrm{Chl} a$ in the $\mathrm{HC}$ pond without mortality $(\mathrm{r}=0.61)$, rather than in the DF pond affected by high shrimp mortality $(r=0.39)$. The analysis of the heterotrophy/autotrophy ratio (assuming that the Chl $a$ concentration mirrors the primary production) illustrated in Fig. 7 shows a strong oscillation of this ratio in the DF pond, which appears to be linked to the mineral nitrogen concentrations and an imbalance in the $\mathrm{N}: \mathrm{P}$ ratio. The negative correlation ( $\mathrm{r}$ $=-0.42)$ between DIN and Chl $a$ concentration and the positive correlation $(\mathrm{r}=0.40)$ between DIP and Chl $a$ (Table 2) strongly suggest that phytoplanktonic variability was induced successively by $\mathrm{N}$ and $\mathrm{P}$ deficiencies in the water column.

Concerning the sediment survey, the organic matter concentration trend (N, C, LOI) and quality (C:N ratio) were found to be similar in the $\mathrm{HC}$ and DF ponds, and concentrations were strongly associated with daily feed input by the farmer. However, TP was higher in HC, implying an imbalance in the TN:TP ratio at DF comparatively to HC. Potential redox values in DF pond suggest that fermentation, $\mathrm{Fe}^{3+}, \mathrm{Mn}^{4+}$ and sulfate reductions could be the main redox reactions occurring in the sediments. $\mathrm{pH}$ indicated an acidity which was more pronounced in $\mathrm{DF}$ than in $\mathrm{HC}$ ponds during the first part of the rearing. $\mathrm{pH}$ variability in the DF pond may be due to the consumption of $\mathrm{H}^{+}$ions by reduction processes (Ponnamperuma, 1972). Sediment at DF was also characterized by high TAN concentrations in pore water, 
which were directly related to the content of $\mathrm{N}$ and $\mathrm{C}$ in sediment (Table 4). However, why did we find a difference of TAN concentrations in pore water at DF compared to HC, despite the fact that similar organic matter concentrations were observed? Berelson et al. (1998) reported that some sediments may be extremely efficient at removing an increased nitrogen load by denitrification. We hypothesise that nitrification, and subsequently denitrification processes, were involved in the removal of the nitrogen load at HC. Because of anoxic conditions, the nitrification process in DF pond was assumed to be inhibited and subsequently denitrification would thus lead to an increase of TAN concentration in pore water. The general consensus is that dissimilatory nitrate reduction to ammonium dominates in carbonrich sediments with low availability of electron acceptors (Christensen et al., 2000). The difference in sand content in the two ponds (22\% at $\mathrm{HC}$ against $9 \%$ at DF) could have an effect on oxygen diffusion and, as a consequence, on nitrification and denitrification processes (Boyd, 1995).

\subsection{Pond environment and potential consequences on the outbreak of disease}

\subsubsection{Environment and shrimp}

It has been shown that stress may affect shrimp immunity (Le Moullac and Haffner, 2000; Horowitz and Horowitz, 2001) and reduce resistance of shrimp to pathogens. Hence we looked for parameters that are potentially stressful for shrimps. In the DF pond, changes in phytoplanktonic biomass were strongly correlated to morning oxygen concentration $(\mathrm{r}=-$ 0.71). DO concentration is one of the main environmental factors which can induce stress in shrimp when it is too low. However, the action of aerators in the two ponds studied prevented anoxia $\left(\left[\mathrm{O}_{2}\right]<2 \mathrm{mg} \mathrm{l}^{-1}\right)$ and stressful values for L. stylirostris $\left(\left[\mathrm{O}_{2}\right]<3 \mathrm{mg} \mathrm{l}^{-1}\right)$ (Mugnier and Soyez, 2005). More generally, it was also shown that crops affected by Summer Syndrome were not specifically related to low morning oxygen values (Lemonnier et al., 2006). 
However, large fluctuations, as observed in the DF pond, could also be a potential source of disturbance for shrimp. During this survey, we did not find any water column value among the physical and chemical parameters studied that can be considered to be stressful for shrimps (Mugnier and Justou, 2004; Mugnier and Soyez, 2005; Mugnier et al., 2008) before the beginning of the mortality outbreak. It has been shown that there is a direct relation between shrimp stress and sediment quality (Lemonnier et al., 2004b; Mugnier et al., 2006). Elevated pore water TAN concentrations in sediment are mostly of concern with respect to the health of cultivated crustaceans (Hargreaves, 1998). In the one hand, our results suggest that sediment characteristics, especially at the end of the survey at DF, could be stressful for shrimps. In the other hand, Burford and Longmore (2001) and Lemonnier et al. (2004a) for intensive rearing systems reported higher TAN values in sediments of ponds showing high survival and yield results. $\mathrm{pH}$ is another important factor with respect to shrimp health (Lemonnier et al., 2004b). pH could be stressful at the beginning of the rearing in DF, and also around d50 in both ponds. More generally, the present work did not show chemical parameter values in the sediment that can by themselves be considered sufficient to explain the mortality outbreak. However, since some of these are close to stressful values, the combination of several parameters and potentially high fluctuations could have led to a physiological stress stronger than those suggested by each parameter separately, as shown by Mugnier et al. (2008) in experimental conditions.

\subsubsection{Environment and pathogen}

The disturbance of the linkage between bacteria and phytoplankton compartments during eutrophication could be determinant when the endemic and highly virulent strain of Vibrio nigripulchritudo is present. Goarant et al. (2007) showed that V. nigripulchritudo bloomed in the column water, at least at the onset of the disease. However, the ecology of the causative 
agent of Summer Syndrome remains, so far, poorly understood and makes it difficult to extrapolate ecological observations from other Vibrio studies in the literature (Worden et al., 2006; Hsieh et al., 2007). The combination of anaerobic conditions (Fig. 6a) and high nutrient levels (Fig. 6c) in sediment could favour V. nigripulchritudo proliferation, as reported for harmful micro-organisms to shrimp (Horowitz and Horowitz, 2001). A positive correlation between the occurrence of Vibrio and organic matter has often been described (La Rosa et al., 2001; 2004). In DF, TAN explains $42 \%$ of the variability of presumptive $V$. nigripulchritudo at DF (Table 4). In HC, presumptive V. nigripulchritudo was detected in the sediment late in the grow-out period but at low concentration, in the samples with the highest TAN concentrations.

\section{Conclusion}

Regarding zootechnical, pathological and various environmental parameters (oxygen, temperature, chl $a$ ), the results obtained in the present survey at DF were typical of those reported by Goarant et al. (2006a) and Lemonnier et al. (2006). They suggest that understanding changes in environmental conditions and microbial ecology could improve our understanding of Summer Syndrome epidemiology. In the farm affected by shrimp disease, exponential phytoplankton growth showed rapid and intense pulses, and their sudden collapses suggested low ecosystem stability and loss of homeostatic mechanisms. The shift from pico- to nanophytoplankton was observed in relation to shrimp mortalities (Lemonnier et al., 2006; this study). Strong phytoplankton oscillations could favour the proliferation of Vibrio nigripulchritudo in the water column. These were linked to an imbalance of N:P ratio in the water column, which could depend on nutrient flux intensity from sediment to the water column. The combination of anaerobic and acidic conditions in the sediments and low ecosystem stability are also potential stress factors that could have weakened the shrimps 
reared in the farm affected by the disease. These conditions could create an environment favouring the proliferation of the pathogen.

\section{Acknowledgements}

This work was supported by a research grant from the Northern Province, Southern Province and Institut Français de Recherche et d'Exploitation de la Mer (IFREMER). We also want to thank D. Ansquer, P. Brun, H. Chartois, D. Coatanea, C. Goarant, E. Goyard, L. Joassard, C. Justou, J. Herlin, F. Imbert, C. Lambert, P. Lemaire, A.L. Marteau, J. Patrois, J.-M. Peignon, E. Pita, J.-M. Ranouil, B. Soulard from Ifremer, S. Jacquet and P. Gérard from IRD, all of whom kindly helped us in this work.

\section{References}

Andrade, L., Gonzalez, A.M., Araujo, F.V., Paranhosa, R., 2003. Flow cytometry assessment of bacterioplankton in tropical marine environments. Journal of Microbiological Methods $55,841-850$.

Alonso-Rodríguez, R., Páez-osuna, F., 2003. Nutrients, phytoplankton and harmful algal blooms in shrimp ponds: a review with special reference to the situation in the Gulf of California. Aquaculture 219, 317-336.

Avnimelech, Y., Ritvo, G., Meijer, L.E., Kochba, M., 2001. Water content, organic carbon and dry bulk density in flooded sediments. Aquacultural Engineering 25, 25-33.

Avnimelech, Y., Ritvo, G., 2003. Shrimp and fish pond soils: processes and management. Aquaculture 220, 549-567.

Bartoli, F., Burtin, G., Herbillon, A.J., 1991. Desegregation and clay dispersion of Oxisols: Na resin, a recommended methodology. Geoderma 49, 301-317. 
Berelson, W.M., Heggie, D., Longmore, A., Kilgore, T., Nicholson, G., Skyring, G., 1998. Benthic nutrient recycling in Port Phillip Bay, Australia. Estuarine, Coastal and Self Science 46, 917-934.

Boyd, C.E., 1995. Bottom soils, sediment, and pond aquaculture. Chapman and Hall editions, New York, USA.

Briand, E., Pringault, O., Jacquet, S., Torréton, J-P., 2004. The use of oxygen microprobes to measure bacterial respiration for determining bacterioplankton growth efficiency. Limnology and Oceanography: Methods 2, 406-416.

Burford, M.A., Williams, K.C., 2001. The fate of nitrogenous waste from shrimp feeding. Aquaculture 198, 79-93.

Burford, M.A., Longmore, A.R., 2001. High ammonium production from sediments in hypereutrophic shrimp ponds. Marine Ecology Progress Series 224, 187-195.

Burford, M.A., Preston, N.P., Glibert, P.M., Dennison, W.C., 2002. Tracing the fate of ${ }^{15}$ Nenriched feed in an intensive shrimp system. Aquaculture 206, 199-216.

Burford, M.A., Thompson, P.J., McIntosh, R.P., Bauman, R.H., Pearson, D.C., 2003a. Nutrient and microbial dynamics in high-intensity, zero-exchange shrimp ponds in Belize. Aquaculture 219, 393-411.

Burford, M.A., Costanzo, S.D., Dennison, W.C., Jackson C.J., Jones, A.B., McKinnon, A.D., Preston, N.P. Trott, L.A., 2003b. A synthesis of dominant ecological processes in intensive shrimp ponds and adjacent coastal environments in NE Australia. Marine Pollution Bulletin 46, 1456-1469.

Christensen, P.B., Rysgaard, S., Sloth, N.P., Dalsgaard, T., Schwaerter, S., 2000. Sediment mineralization, nutrient fluxes, denitrification and dissimilatory nitrate reduction to ammonium in an estuarine fjord with sea cage trout farms. Aquatic microbial ecology 21, 73-84. 
Cole, J.J., Findlay, S., Pace, M.L., 1988. Bacterial production in fresh and saltwater ecosystems: across-system overview. Marine Ecology Progress Series 43, 1-10.

Ducklow, H.W., Carlson, C.A., 1992. Oceanic bacterial productivity. Advances in Microbial Ecology 12, 113-181.

Fernández, E., Marañón, E., Morán, X.A.G., Serret, P., 2003. Potential causes for the unequal contribution of picophytoplankton to total biomass and productivity in oligotrophic waters. Marine Ecology Progress Series 254, 101-109.

Frederick, J.A., Schelske, C.L., Carrick, H.J., 1993. Nutrient limitation in a hypereutrophic Florida lake. Archiv für Hydrobiogie 7, 21-37.

Fukuda, R., Ogawa, H., Nagata, T., Koike, I., 1998. Direct Determination of Carbon and Nitrogen Contents of Natural Bacterial Assemblages in Marine Environments. Applied and environmental microbiology 64, 3352-3358.

Gasol, J.M., Zweifel, U.L., Peters, F., Fuhrman, J.A., Hagström Å., 1999. Significance of Size and Nucleic Acid Content Heterogeneity as Measured by Flow Cytometry in Natural Planktonic Bacteria. Applied and Environmental Microbiology 65, 4475-4483.

Goarant, C., Ansquer, D., Herlin, J., Domalain, D., Imbert, F., and De Decker, S., 2006a. "Summer syndrome" in Litopenaeus stylirostris in New Caledonia: Pathology and epidemiology of the etiological agent, Vibrio nigripulchritudo. Aquaculture 253, 105-113.

Goarant, C., Reynaud, Y., Ansquer, D., de Decker, S., Saulnier, D., Le Roux, F., 2006 b. Molecular epidemiology of Vibrio nigripulchritudo, a pathogen of cultured penaeid shrimp (Litopenaeus stylirostris) in New Caledonia. Systematic and Applied Microbiology 29, 570-580.

Goarant, C., Reynaud, Y., Ansquer, D., de Decker, S., Merien, F, 2007. Sequence polymorphism-based identification and quantification of Vibrio nigripulchritudo at the 
species and subspecies level targeting an emerging pathogen for cultured shrimp in New Caledonia. Journal of Microbiological Methods 70, 30-38.

Hargreaves, J.A., 1998. Nitrogen biogeochemistry of aquaculture ponds. Aquaculture 166, $181-212$

Hedges, J.I., Stern, J.H., 1984. Carbon and nitrogen determinations of carbonate-containing solids. Limnology and Oceanography 29, 657-663.

Holm-Hansen, O., Lorenzen, C.J., Holmes, P.E., Strickland, J.D.H., 1965. Fluorometric determination of chlorophyll. Journal du conseil international pour l'exploitation de la mer 30, 3-15.

Horowitz, A., Horowitz, S., 2001. Disease control in shrimp aquaculture from a microbial ecology perspective. In: Browdy C.L. and Jory D.E., editors. 2001. The New Wave, Proceedings of the Special Session on Sustainable Shrimp Culture, Aquaculture 2001. The World Aquaculture Society, Baton Rouge, Baton Rouge, Louisiana, United States, pp. 199-218.

Hussenot, J., Martin, J.L.M., 1995. Assessment of the quality of pond sediment in aquaculture using simple rapid techniques. Aquaculture International 3, 123-133.

Hsieh, J.L., Fries, J.S., Noble, R.T., 2007. Vibrio and phytoplankton dynamics during the summer of 2004 in a eutrophying estuary. Ecological Applications 17(5) Supplement, S102-S109.

Koroleff, F., 1976. Determination of ammonia, in methods in seawater analysis (Grasshof K.; ed.), Verlag chemie, Weineim, RFA, 126-133.

La Rosa, T., Mirto, S., Mazzola, A., Danovaro, R., 2001. Differential responses of benthic microbes and meiofauna to fish-farm disturbance in coastal sediments. Environmental Pollution 112, 427-434. 
La Rosa, T., Mirto, S., Mazzola, A., Luciana Maugeri, T., 2004. Benthic microbial indicators of fish farm impact in a coastal area of the Tyrrhenian Sea. Aquaculture 230, 153-167.

Le Moullac, G., Haffner, P., 2000. Environmental factors affecting immune responses in Crustacea. Aquaculture 191, 121-131.

Lebaron, P., Servais, P., Agogue, H., Courties, C., Joux, F., 2001. Does the high nucleic acid content of individual bacterial cells allow us to discriminate between active cells and inactive cells in aquatic systems? Applied and Environmental Microbiology 67, 17751782.

Lemonnier, H., Brizard, R., Legrand, A., 2004a. Influence des pratiques zootechniques de la crevette (Litopenaeus stylirostris) et de l'âge des bassins sur la qualité des sédiments. In : Styli 2003. Trente ans de crevetticulture en Nouvelle Calédonie. Nouméa-Koné, 2-6 juin 2003. Ed. IFREMER, Actes Colloq., 38, 180-186.

Lemonnier, H., Bernard, E., Boglio, E., Goarant, C., Cochard, J-C., 2004b. Influence of sediment characteristics on shrimp physiology: $\mathrm{pH}$ as principal effect. Aquaculture 240, 297-312.

Lemonnier, H., Faninoz, S., 2006. Effects of water exchange rate on effluent and sediment characteristics and on partial nitrogen budget in semi-intensive shrimp ponds in New Caledonia. Aquaculture Research, 37, 938-948.

Lemonnier, H., Herbland, A., Salery, L., Soulard, B., 2006. "Summer syndrome" in Litopenaeus stylirostris grow out ponds in New Caledonia: zootechnical and environmental factors. Aquaculture 261, 1039-1047.

Lemonnier H., 2007. Effet des conditions environnementales sur le développement des pathologies à Vibrio dans les élevages de crevettes en Nouvelle Calédonie. Thèse de l’Université de La Rochelle, Discipline Océanologie biologique, 203 pp. http://www.ifremer.fr/docelec/ 
Lightner, D.V., Redman, R.M., 1998. Shrimp diseases and current diagnostic methods. Aquaculture 164, 201-220.

Marie, D., Partensky, F., Jacquet S., Vaulot, D., 1997. Enumeration and Cell Cycle Analysis of Natural Populations of Marine Picoplankton by Flow Cytometry Using the Nucleic Acid Stain SYBR Green I. Applied and Environmental. Microbiology 63, 186-193.

Martin, J-L.M., Veran, Y., Guelorget, O., Pham, D., 1998. Shrimp rearing: stocking density, growth, impact on sediment, waste output and their relationships studied through the nitrogen budget in rearing ponds. Aquaculture 164, 135-149.

McCarthy, M.D., Hedges, J.I., Benner, R., 1998. Major bacterial contribution to marine dissolved organic nitrogen. Science 281, 135-149.

Mugnier, C., Justou, C., 2004. Combined effect of external ammonia and molt stage on the blue shrimp Litopenaeus stylirostris physiological response. Journal of Experimental Marine Biology and Ecology 309, 35-46.

Mugnier, C., Soyez, C., 2005. Response of the blue shrimp Litopenaeus stylirostris to temperature decrease and hypoxia in relation to molt stage. Aquaculture 244, 315-322.

Mugnier, C., Justou, C., Personnel du LAC, 2004. La crevette et le syndrome d'été en Nouvelle-Calédonie: quelles réponses physiologiques et immunitaires? Résultats préliminaires du programme Désans. In: Styli 2003. Trente ans de crevetticulture en Nouvelle Calédonie. Nouméa-Koné, 2-6 juin 2003. Ed. IFREMER, Actes Colloq., 38, 8592.

Mugnier, C., Lemonnier, H., Legrand, A., 2006. Physiological response of the blue shrimp Litopenaeus stylirostris to short-term confinement on a pond bottom. Aquaculture 253, 703-711. 
Mugnier, C., Zipper, E., Goarant, C., Lemonnier, H., 2008. Effect of exposure to ammonia and hypoxia on the blue shrimp Litopenaeus stylirostris survival and physiological response in relation to molt stage. Aquaculture 274, 398-407.

Murphy, J., Riley, J.P., 1962. A modified single solution method for the determination of phosphate in natural waters. Analytica Chimica Acta 26, 31-36.

Nelson, D.W., Sommers, L.E., 1982. Total carbon, organic carbon, and organic matter. In Methods of soil analysis: Part 2, chemical and microbiological properties, A.L. Page, R.H. Miller, and D.R. Keeney, eds, pp. 539-579. American Society of Agronomy and Soil Science Society of America, Madison, Wisc.

Ponnamperuma, F.N., Martinez, E., Loy T., 1966. Influence of redox potential and partial pressure of carbon dioxide on $\mathrm{pH}$ values and the suspension effect of flooded soils. Soil Science 101, 421-431.

Ponnamperuma, F.N., 1972. The chemistry of submerged soils. Advances in Agronomy 24, 29-96.

Queiroz, J.F., Boyd, C.E., 1998. Evaluation of a kit for estimating organic matter concentrations in bottom soils of aquaculture ponds. Journal of the World Aquaculture Society 29, 230-233.

Raimbault, P., Slawyk, G., Coste, B., Fry, J.C., 1990. Feasibility of measuring an automated colorimetric procedure for the determination of seawater nitrate in the 0 and $100 \mathrm{nM}$ range: Examples from field and culture. Marine Biology 104, 347-351.

Raimbault, P., Pouvesle, W., Diaz, F., Garcia, N., Sempéré, R., 1999. Wet-oxidation and automated colorimetry for simultaneous determination of organic carbon, nitrogen and phosphorus dissolved in seawater. Marine Chemistry 66, 161-169.

Reynaud, Y., Saulnier, D., Mazel, D., Goarant, C., Le Roux, F., 2008. Correlation between detection of a Plasmid and high-level virulence of Vibrio nigripulchritudo, a pathogen of 
the shrimp Litopenaeus stylirostris. Applied and Environmental Microbiology 74, 30383047.

Rochelle-Newall, E.J., Torréton, J.-P., Mari, X., Pringault, O., 2008. Phytoplankton bacterioplankton coupling in a subtropical South Pacific coral reef lagoon. Aquatic Microbial Ecology 50, 221-229.

Seitzinger, S.P., 1988. Denitrification in freshwater and coastal marine ecosystems: ecological and geochemical significance. Limnology and Oceanography 33, 702-724.

Smith D. C., Azam F., 1992. A simple, economical method for measuring bacterial protein synthesis rates in seawater using 3H-leucine. Marine Microbial Food Webs 6, 107-114

Snieszko, S.F., 1974. The effect of environmental stress on outbreaks of infectious diseases of fish. Journal of Fisheries Biology 6, 197-208.

Sommaruga, R., Robarts, R.D., 1997. The significance of autotrophic and heterotrophic picoplankton in heterotroph ecosystems. FEMS Microbiology Ecology 24, 187-200.

Torréton, J.-P., Rochelle-Newall, E., Jouon, A., Faure, V., Jacquet, S., Douillet, P., 2007 Correspondence between the distribution of hydrodynamic time parameters and the distribution of biological and chemical variables in a semi-enclosed coral reef lagoon Estuarine, Coastal and Shelf Science 74, 766-776.

Treguer, P., Le Corre, P., 1975. Manuel d'analyses des sels nutritifs dans l'eau de mer. Utilisation de l'autoanalyseur II, Technicon R. Rapport U.B.O., 110 p.

Vaulot, D., Courties, C. and Partensky, F., 1989. A simple method to preserve oceanic phytoplankton for flow cytometric analyses. Cytometry, 10(5), 629-635.

Williams, C.J., Lavrentyev, P.J., Jochem, F.J., 2008. Bottom-up and top-down control of heterotrophic bacterioplankton growth in a phosphorus-depleted subtropical estuary, Florida Bay, USA. Marine Ecology Progress Series 372, 7-18. 
Worden, A.Z., Seide, M., Smriga, S., Wick, A., Malfatti, F., Bartlett, D., Azam, F., 2006.

Trophic regulation of Vibrio cholerae in coastal marine waters. Environmental Microbiology 8(1), 21-29. 
Table 1. Spearman's rank correlation between parameters and time in the water column.

\begin{tabular}{lll}
\hline Parameters & HC & DF \\
\hline $\mathrm{T}$ & $0.68^{* *}$ & $0.63^{* *}$ \\
$\mathrm{DO}$ & $-0.67^{* *}$ & $-0.79^{* *}$ \\
$\Delta \mathrm{DO}$ & $0.67^{* *}$ & $0.60^{* *}$ \\
$\mathrm{pH}$ & -0.03 & $-0.43^{* *}$ \\
$\mathrm{DIN}$ & -0.15 & -0.18 \\
$\mathrm{DIP}$ & $-0.29^{*}$ & $0.41^{* *}$ \\
$\mathrm{~N}: \mathrm{P}$ ratio & $-0.29^{*}$ & $-0.30^{*}$ \\
$\mathrm{DON}$ & 0.24 & 0.05 \\
$\mathrm{DOC}$ & 0.21 & -0.03 \\
$\mathrm{Chl} a$ & $0.89^{* *}$ & $0.81^{* *}$ \\
$\mathrm{POC}$ & $0.84^{* *}$ & $0.75^{* *}$ \\
$\mathrm{PON}$ & 0.24 & 0.05 \\
$\mathrm{BP}$ & $0.70^{* *}$ & $0.51^{* *}$ \\
TBA & 0.13 & 0.20 \\
$\mathrm{HNA}$ & -0.15 & -0.02 \\
\hline
\end{tabular}

*: $\mathrm{P}<0.05 ; * *: \mathrm{P}<0.01 ; \mathrm{T}$, temperature; DO, dissolved oxygen; $\triangle \mathrm{DO}$, net dissolved oxygen budget; DIN, dissolved inorganic nitrogen, DIP, dissolved inorganic phosphorus; N:P ratio, DIN:DIP ratio; DON, dissolved organic nitrogen; DOC, dissolved organic carbon; Chl $a$, chlorophyll $a$; POC, particulate organic carbon; PON, particulate organic nitrogen; $\mathrm{BP}$, bacterial production; TBA, total bacteria abundance; HNA, total HNA abundance (HNA: high nucleic acid content). 
Table 2. Pearson's correlation coefficients between chlorophyll $a$ (Chl $a$ ), bacterial production (BP), total bacteria abundance (TBA), high nucleic acid content bacteria abundance (HNA) and feed, temperature (T), dissolved oxygen (DO), particulate organic carbon (POC), particulate organic nitrogen (PN), dissolved organic carbon (DOC), dissolved organic nitrogen (DON), dissolved inorganic nitrogen (DIN), dissolved inorganic phosphorus (DIP), molar DIN:DIP ratio(N:P ratio) in the water column of each pond at $06 \mathrm{~h} 00\left(\mathrm{~N}_{\mathrm{HC}}=55\right.$; $\left.\mathrm{N}_{\mathrm{DF}}=60\right) . * *: \mathrm{P}<0.01, *: \mathrm{P}<0.05$, otherwise not significant.

\begin{tabular}{lcccccccc}
\hline & \multicolumn{2}{c}{$\mathrm{Chl} a$} & \multicolumn{2}{c}{$\mathrm{BP}$} & \multicolumn{2}{c}{ TBA } & \multicolumn{2}{c}{ HNA } \\
\hline & $\mathrm{HC}$ & $\mathrm{DF}$ & $\mathrm{HC}$ & $\mathrm{DF}$ & $\mathrm{HC}$ & $\mathrm{DF}$ & $\mathrm{HC}$ & $\mathrm{DF}$ \\
\hline Chl $a$ & - & - & & & & & & \\
BP & $0.61^{* *}$ & $0.39^{* *}$ & - & - & & & & \\
TBA & 0.25 & $0.31^{*}$ & $0.45^{* *}$ & $0.38^{* *}$ & - & - & & \\
HNA & $0.29^{*}$ & $0.13^{*}$ & $0.49^{* *}$ & $0.31^{*}$ & $0.90^{* *}$ & $0.85^{* *}$ & - & - \\
Feed & $0.71^{* *}$ & $0.79^{* *}$ & $0.41^{* *}$ & $0.48^{* *}$ & 0.07 & $0.37^{* *}$ & -0.10 & 0.20 \\
T & $0.67^{* *}$ & $0.49^{* *}$ & $0.59^{* *}$ & 0.19 & 0.09 & 0.16 & 0.19 & -0.00 \\
DO & $-0.48^{* *}$ & $-0.71^{* *}$ & $-0.31^{*}$ & $-0.62^{* *}$ & -0.08 & $-0.31^{*}$ & -0.04 & -0.12 \\
POC & $0.91^{* *}$ & $0.89^{* *}$ & $0.62^{* *}$ & $0.39^{* *}$ & $0.27^{*}$ & 0.26 & $0.35^{* *}$ & 0.15 \\
PON & $0.87^{* *}$ & $0.90^{* *}$ & $0.66^{* *}$ & $0.47^{* *}$ & $0.36^{* *}$ & $0.28^{*}$ & $0.40^{* *}$ & 0.19 \\
DOC & $0.48^{* *}$ & 0.19 & 0.30 & 0.15 & 0.33 & 0.01 & $0.49 * *$ & -0.07 \\
DON & 0.23 & 0.11 & $0.37^{* *}$ & -0.09 & 0.10 & 0.18 & 0.25 & 0.15 \\
DIN & -0.12 & $-0.42^{* *}$ & -0.08 & 0.20 & 0.14 & 0.08 & 0.25 & 0.00 \\
DIP & -0.08 & $0.40^{* *}$ & 0.11 & 0.11 & $0.28^{*}$ & -0.10 & 0.19 & -0.21 \\
N:P ratio & $0.34^{*}$ & $-0.56^{* *}$ & 0.10 & 0.01 & -0.18 & 0.09 & -0.03 & 0.11 \\
\hline
\end{tabular}


Table 3. Spearman's rank correlation between parameters and time in sediment.

\begin{tabular}{lll}
\hline Parameters & HC & DF \\
\hline $\mathrm{pH}$ & $-0.69^{*}$ & -0.11 \\
Eh & $-0.37 * *$ & 0.12 \\
TAN & 0.27 & $0.60 * *$ \\
DIP & $-0.31^{*}$ & $0.41 * *$ \\
LOI & $0.44^{*}$ & $0.69 * *$ \\
TOC & $0.56 * *$ & $0.72 * *$ \\
TN & $0.61 * *$ & $0.77 * *$ \\
C/N ratio & $-0.33^{*}$ & $-0.52^{* *}$ \\
TP & $0.35^{*}$ & $0.36 *$ \\
\hline *: P < 0.05; **: P < 0.01 & (Eh: redox potential; TAN: total \\
ammonia nitrogen; DIP: dissolved inorganic phosphorus; LOI: \\
loss by ignition; TOC: total organic carbon; TN: total nitrogen; \\
TP: total phosphorus)
\end{tabular}


Table 4. Pearson's correlation coefficients among sediment parameters in DF and HC ponds. *: $\mathrm{P}<0.05 ; * *: \mathrm{P}<0.01$; Eh: redox potential; TAN: total ammonia nitrogen; DIP: dissolved inorganic phosphorus; LOI: loss by ignition; TOC: total organic carbon; TN: total nitrogen; TP: total phosphorus; Vn: Presumptive Vibrio nigripulchritudo abundance.

\begin{tabular}{|c|c|c|c|c|c|c|c|c|c|}
\hline & $\mathrm{pH}$ & Eh & TAN & DIP & LOI & TOC & TN & $\mathrm{TP}$ & $\mathrm{Vn}$ \\
\hline$\overline{\mathrm{pH}}$ & - & $0.39 * *$ & -0.01 & 0.09 & $-0.51 * *$ & $-0.58 * *$ & $-0.62 * *$ & -0.21 & -0.18 \\
\hline Eh & $-0.52 * *$ & - & -0.22 & $0.33^{*}$ & $-0.34 * *$ & $-0.47 * *$ & $-0.47 * *$ & -0.09 & -0.17 \\
\hline TAN & 0.08 & $-0.26^{*}$ & - & 0.09 & -0.03 & $0.43^{* *}$ & 0.13 & 0.30 & $0.36^{* *}$ \\
\hline DIP & 0.05 & -0.14 & $0.48 * *$ & - & -0.11 & 0.34 & -0.09 & $0.44^{*}$ & 0.15 \\
\hline LOI & -0.18 & 0.21 & $0.45^{* *}$ & 0.25 & - & $0.88 * *$ & $0.85^{* *}$ & $0.51 * *$ & $0.24^{*}$ \\
\hline TOC & -0.19 & 0.14 & $0.54 * *$ & $0.53 * *$ & $0.90 * *$ & - & $0.96^{* *}$ & $0.70 * *$ & $0.35^{*}$ \\
\hline $\mathrm{TN}$ & -0.16 & 0.19 & $0.49 * *$ & $0.34 *$ & $0.69 * *$ & $0.95 * *$ & - & $0.65 * *$ & $0.23^{*}$ \\
\hline $\mathrm{TP}$ & 0.08 & 0.01 & 0.26 & $0.45 *$ & $0.46^{* *}$ & $0.49 * *$ & $0.47 * *$ & - & 0.19 \\
\hline $\mathrm{Vn}$ & 0.12 & 0.10 & $0.42 * *$ & $0.37 * *$ & $0.51 * *$ & $0.51 * *$ & $0.57 * *$ & $0.37 *$ & - \\
\hline
\end{tabular}


a

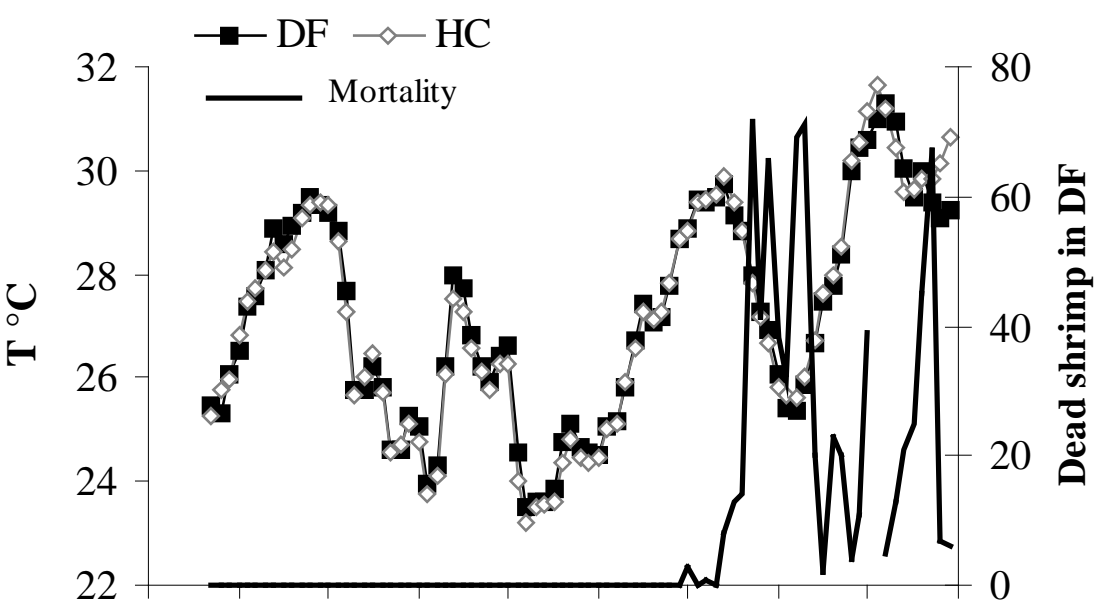

b

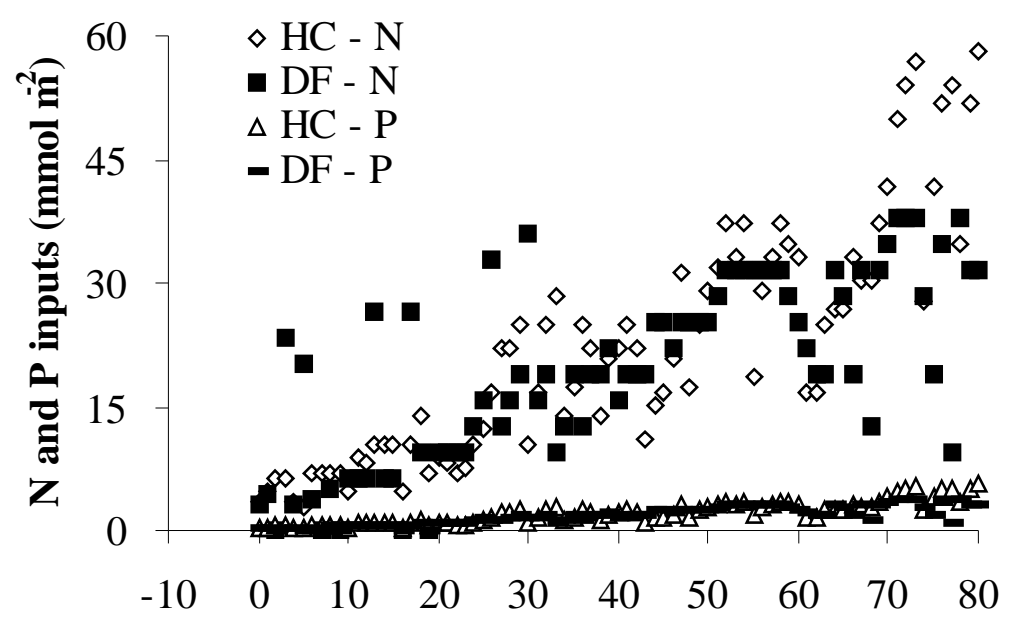

Days

Fig. 1. (a) Daily average temperature in the two ponds and mortality linked to the summer syndrome in the DF pond; (b) Nitrogen and phosphorus inputs with feed and fertilizer in ponds. 
a

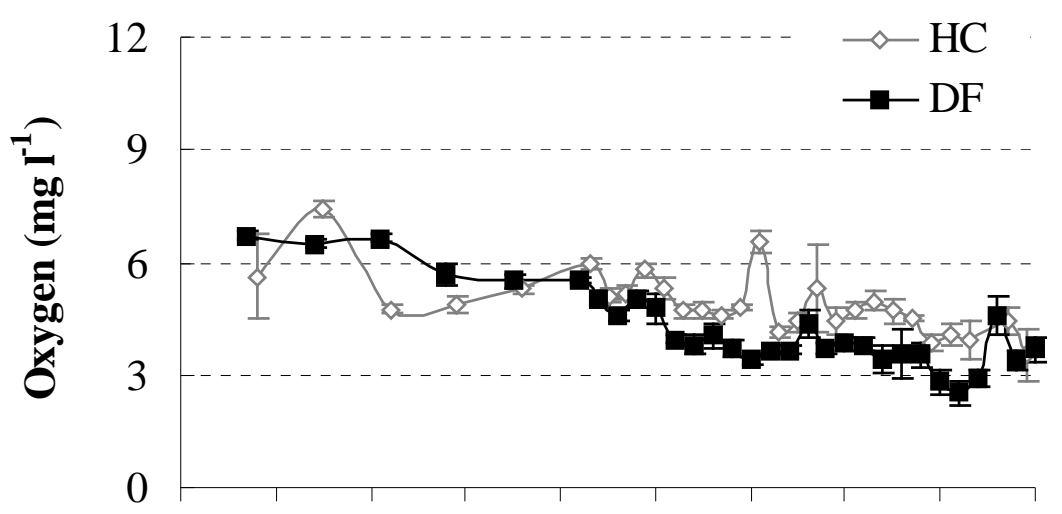

b

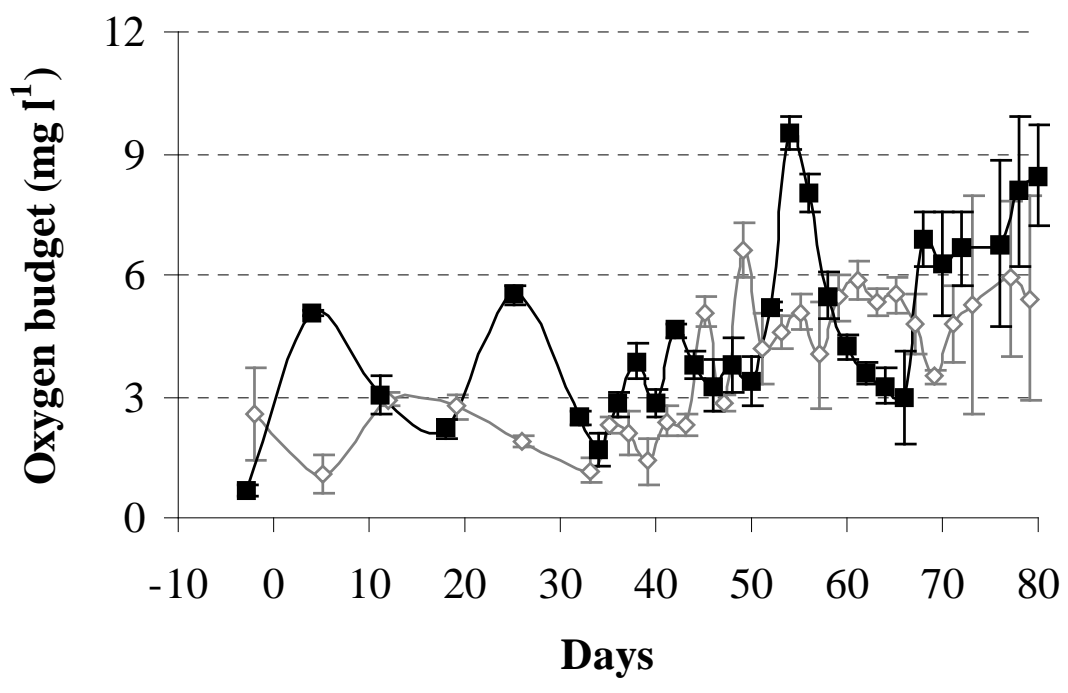

Fig. 2. (a) Morning average oxygen concentrations and (b) net oxygen budgets (16h00 values minus $06 \mathrm{~h} 00$ values) versus time measured in three stations at two depths in each pond. Bars represent standard deviation $(\mathrm{N}=6)$. 
$\mathbf{a}$

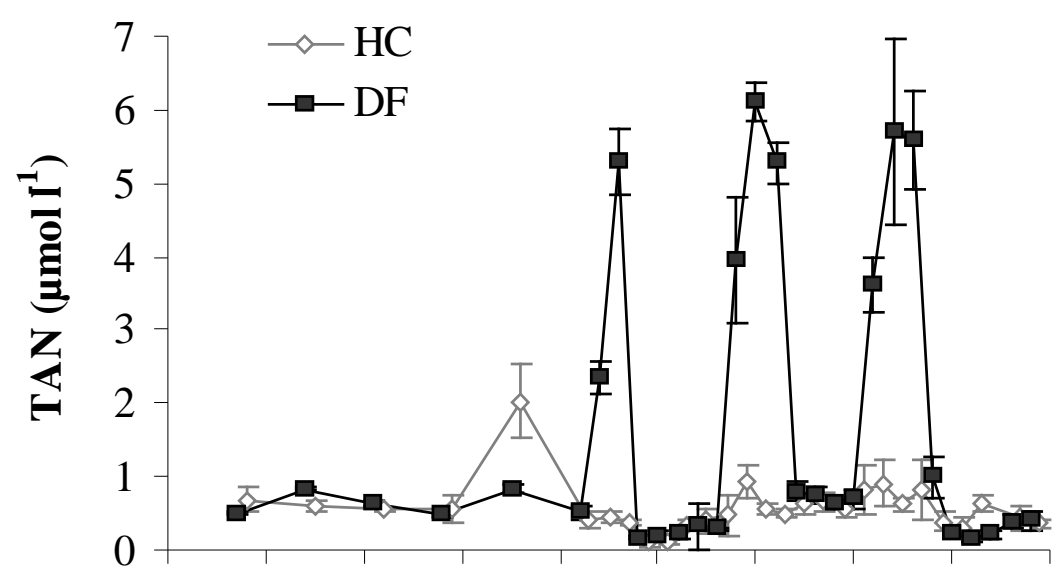

b

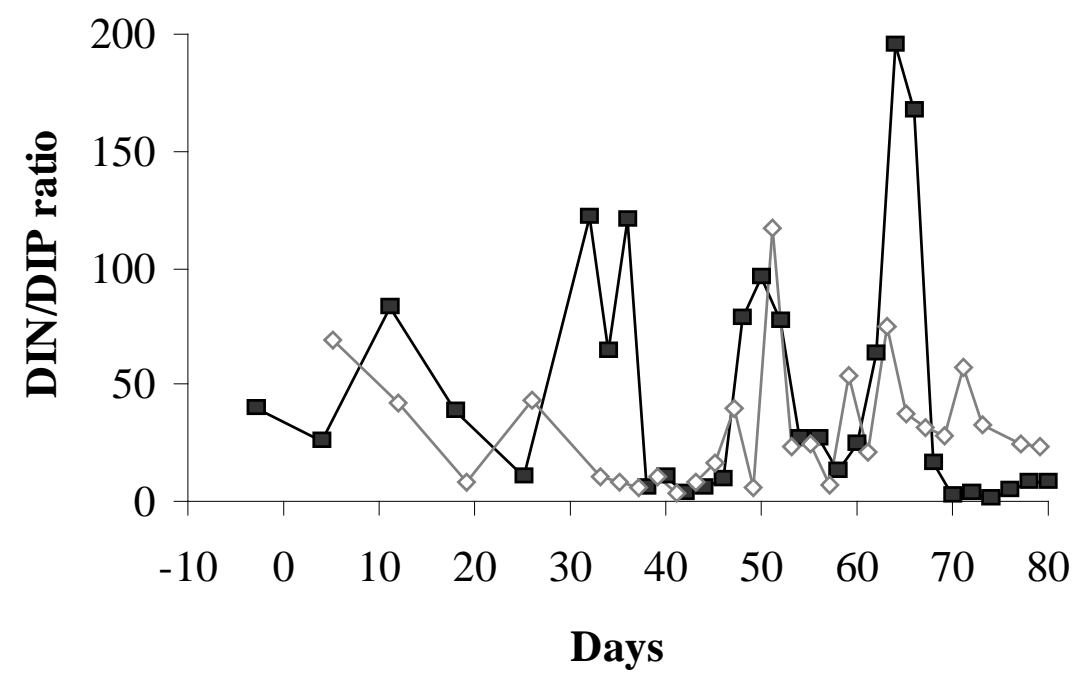

Fig. 3. (a) Average TAN concentrations $(\mathrm{N}=6)$ measured in three stations at two depths and (b) DIN/DIP ratio $(\mathrm{N}=2)$ in each of $\mathrm{HC}$ and $\mathrm{DF}$ ponds in relation to time. TAN: total ammonia nitrogen; DIN: dissolved inorganic nitrogen; DIP: dissolved inorganic phosphorus. 

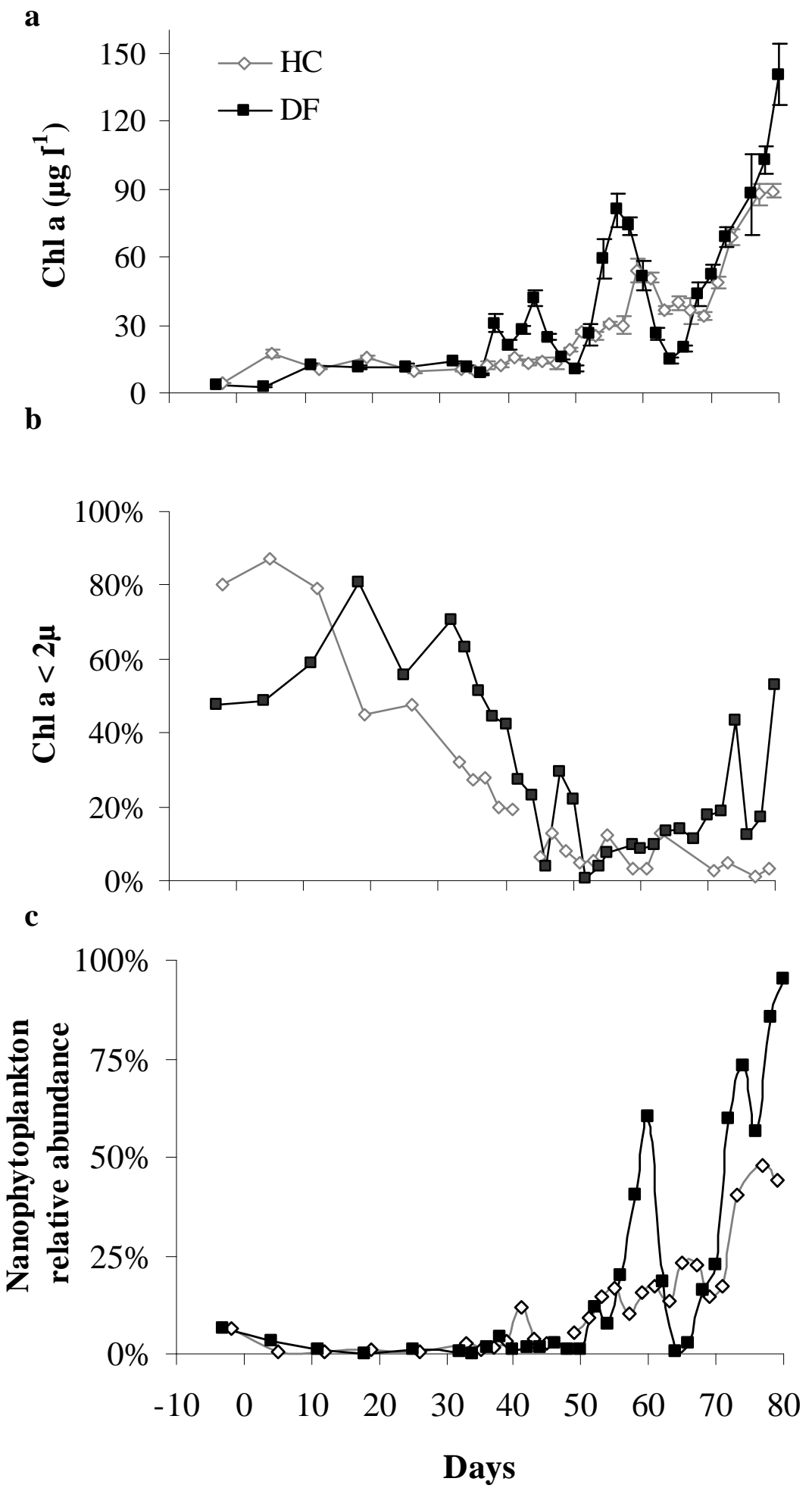

Fig. 4. Temporal variations of mean (a) total chlorophyll $a$ concentrations (Chl $a)(a)(\mathrm{N}=6)$, (b) percent contribution of Chl $a$ content in cells minus than $2 \mu \mathrm{m}$ to total $\mathrm{Chl} a$ and (c) nanophytoplankton relative abundance $(\mathrm{N}=2)$ in $\mathrm{HC}$ and $\mathrm{DF}$ ponds. 


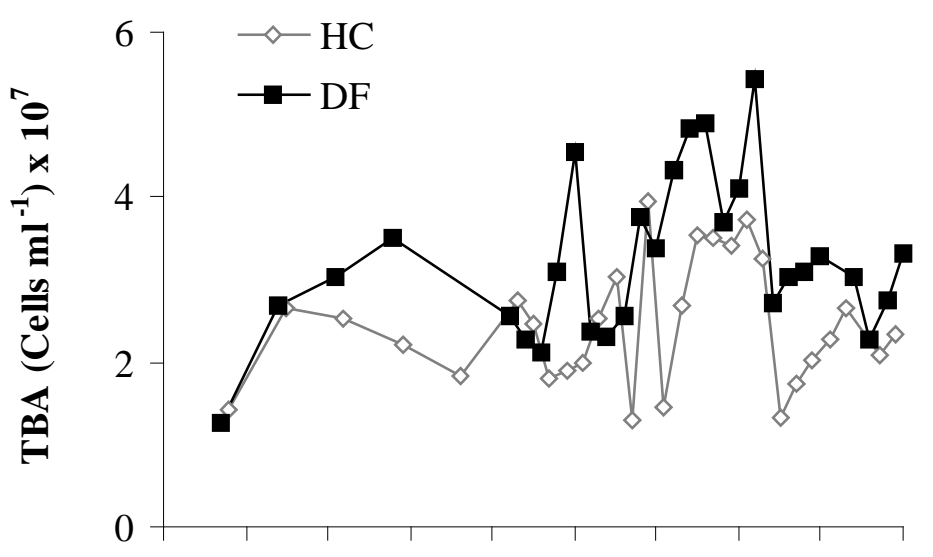

b

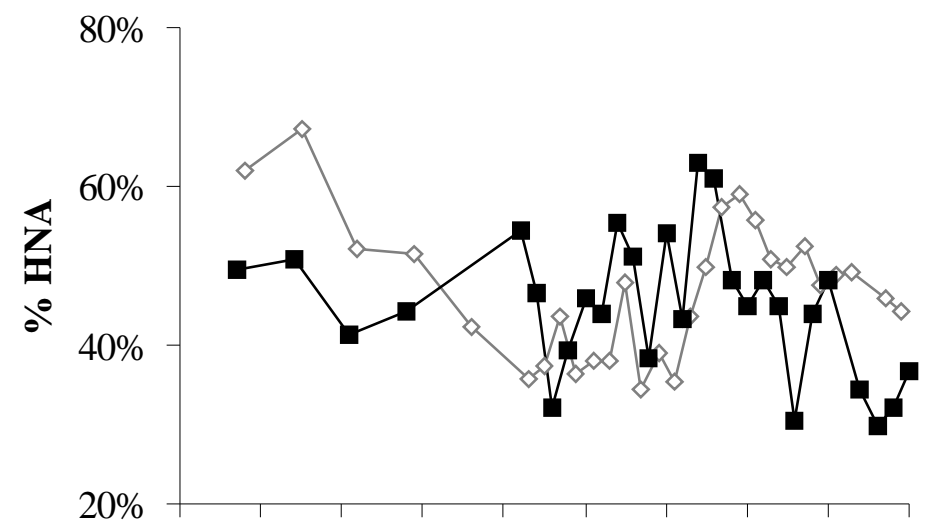

c

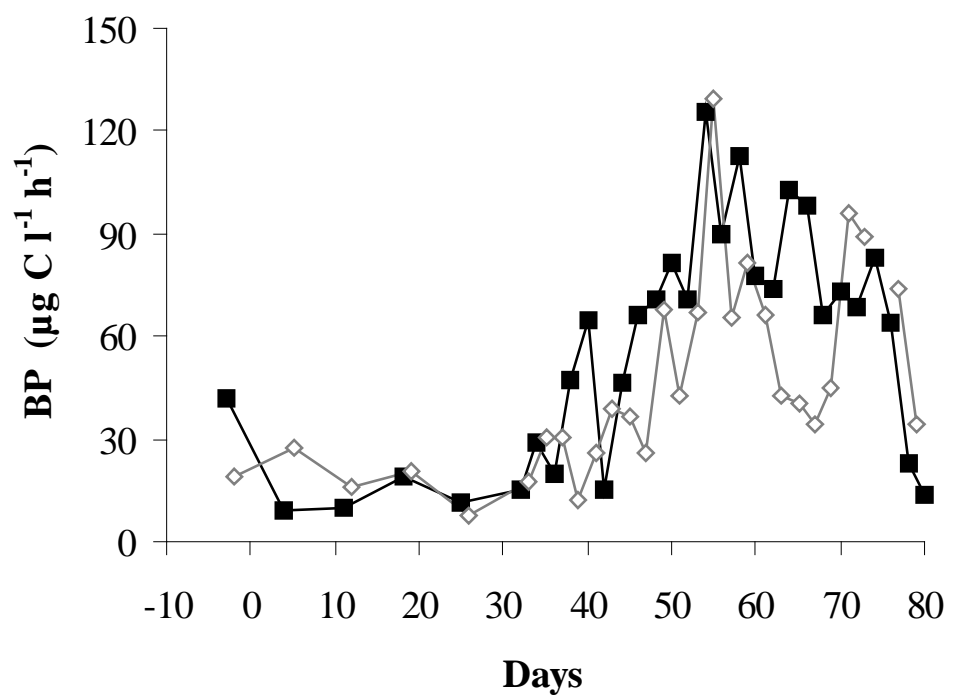

Fig. 5. Total bacterial abundance (TBA), percent high DNA content bacteria (\% HNA) and bacterial production $(\mathrm{BP})$ in $\mathrm{HC}$ and $\mathrm{DF}$ ponds versus time $(\mathrm{N}=2)$. 
a

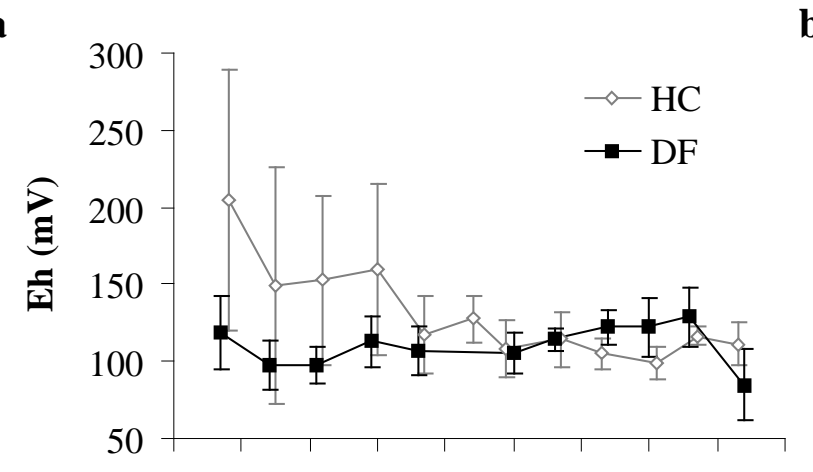

c

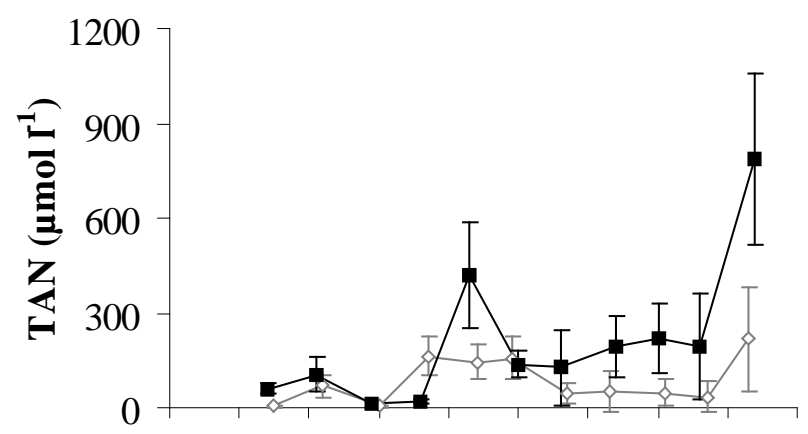

e

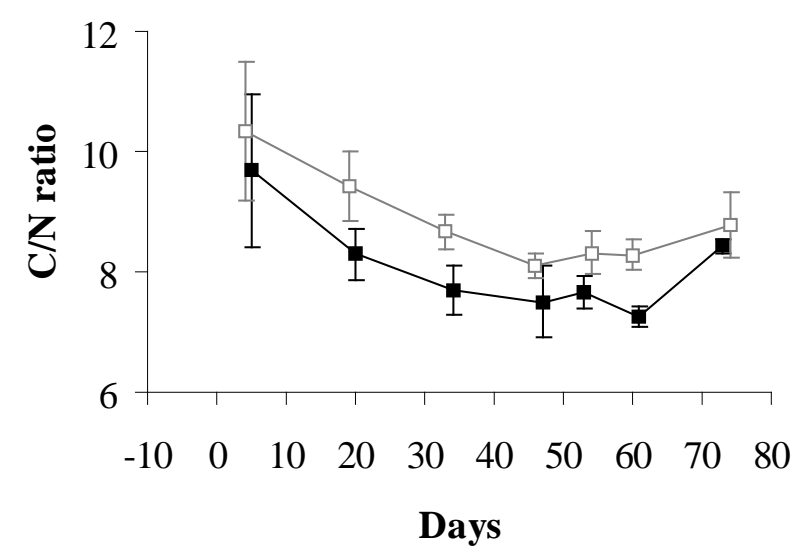

b

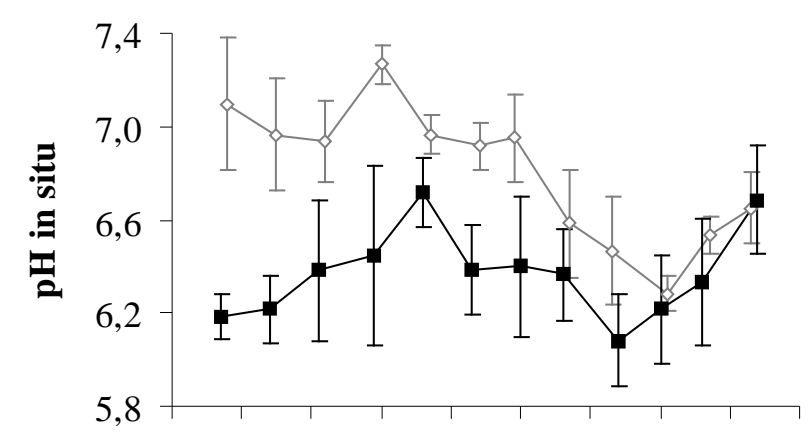

d

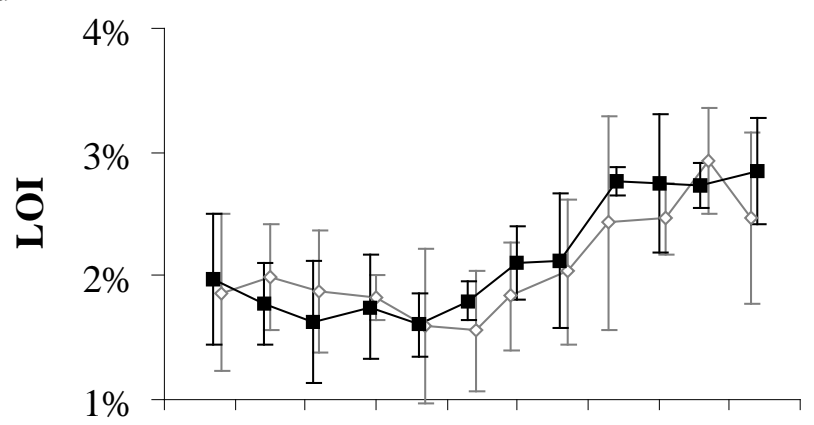

f

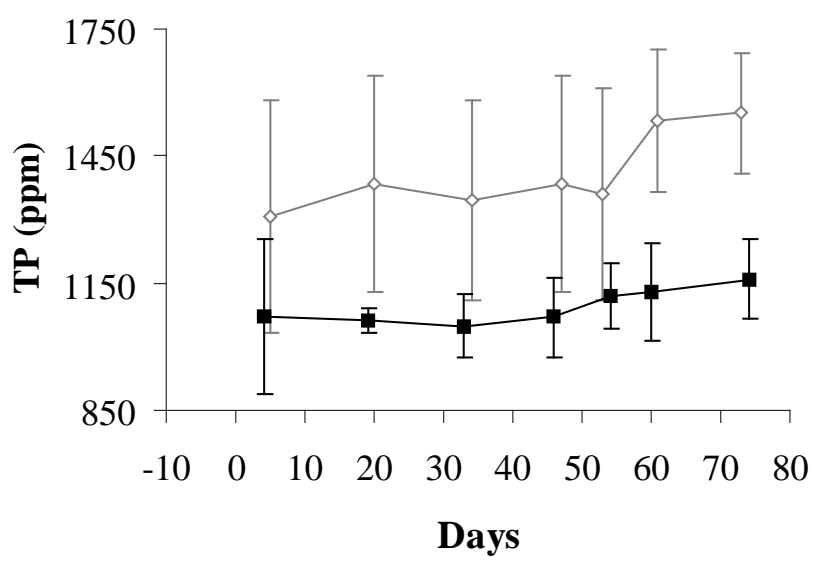

Fig. 6. Mean $( \pm \mathrm{SD}$ ) of (a) redox potential (Eh), (b) $\mathrm{pH}$, (c) total ammonia nitrogen in pore water (TAN), (d) loss by ignition (LOI) in the sediment, (e) carbon / nitrogen ratio in the sediment, and (f) total phosphorus in the sediment over the 80-days survey $(\mathrm{N}=6)$ in $\mathrm{HC}$ and DF ponds. Bars represent standard deviation. 


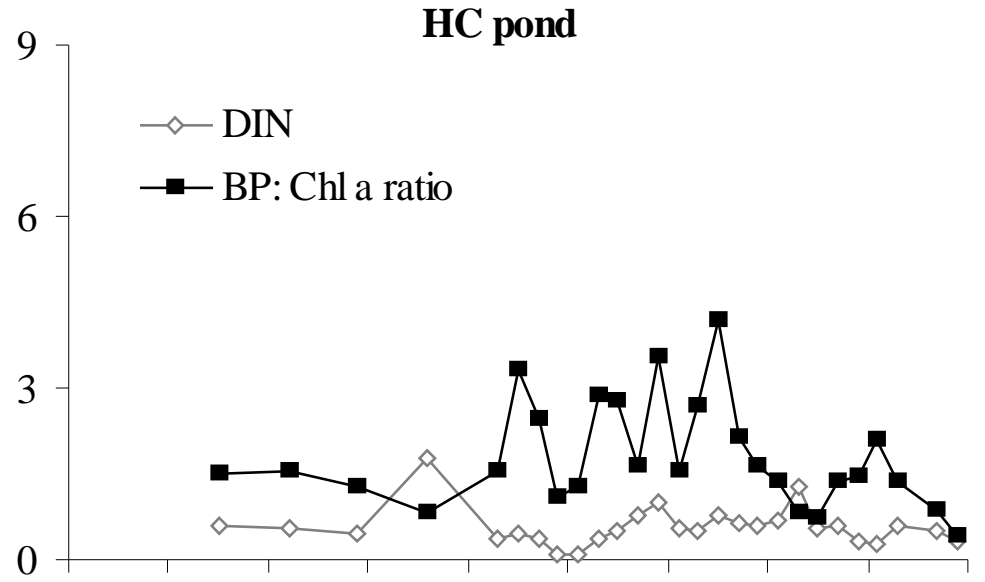

b

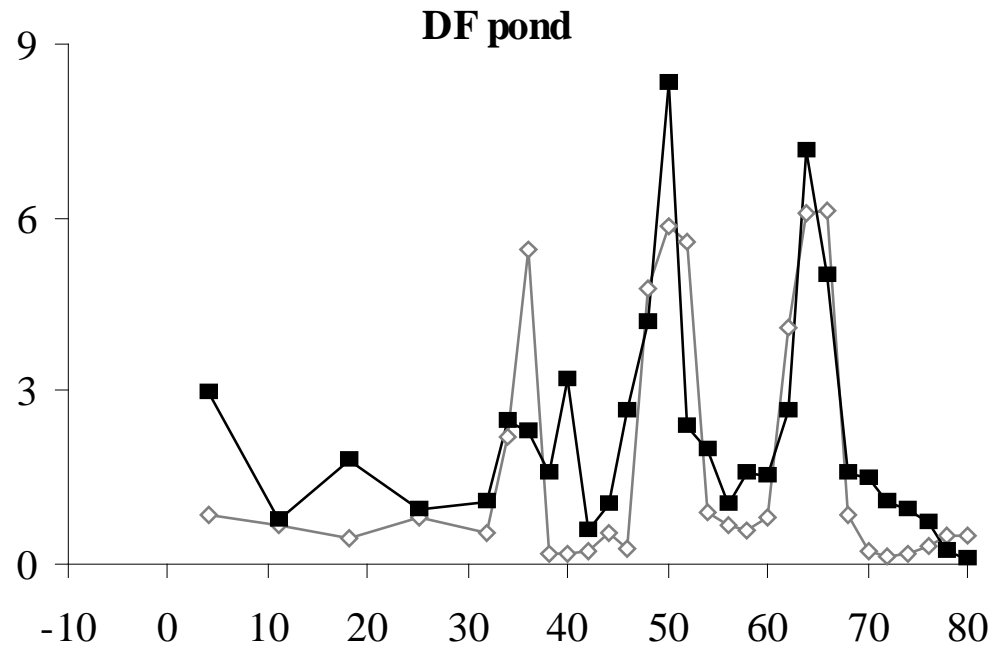

Fig. 7. BP:Chl $a$ ratio (BP $\mu \mathrm{g} \mathrm{Cl}^{-1} \mathrm{~h}^{-1}, \mathrm{Chl} a \mu \mathrm{gl}^{-1}$ ) and DIN ( $\mu \mathrm{mol} \mathrm{l}^{-1}$ ) in relation to time in HC and DF ponds. BP: bacterial production; Chl $a$ : chlorophyll $a$; DIN: dissolved inorganic nitrogen. 